\title{
REINSTATEMENT OF DESMOS SUBBIGLANDULOSUS (ANNONACEAE) IN BORNEO
}

\author{
Isna Arofatun Nikmah ${ }^{1}$, Tatik Chikmawati ${ }^{2} \&$ Rugayah $^{3}$ \\ ${ }^{1}$ Plant Biology Graduate Program, Department of Biology, Faculty of Mathematics and Natural Sciences, \\ IPB University, Indonesia \\ ${ }^{2}$ Department of Biology, Faculty of Mathematics and Natural Sciences, IPB University, Bogor, Indonesia \\ ${ }^{3}$ Herbarium Bogoriense, Indonesia Institute of Sciences, Cibinong 16911, Bogor \\ Correspondence: tchikmawati@yahoo.com
}

Isna Arofatun Nikmah, Tatik Chikmawati \& Rugayah. 2019. Pengembalian Status dan Kedudukan Desmos subbiglandulosus (Annonaceae) di Borneo. Floribunda 6(3): 98-102. - Desmos subbiglandulosus (Miq.) Merr, yang sebelumnya disinonimkan dengan Desmos dumosus (Roxb.)Saff., diterima kembali berdasarkan pengamatan spesimen herbarium dan spesimen type D. subbiglandulosus dari Borneo yang disimpan di Herbarium Bogoriense. Spesimen-spesimen D. subbiglandulosus dan D. dumosus banyak memiliki perbedaan morfologi. Semua spesimen Desmos dari Borneo yang sebelumnya diidentifikasi sebagai $D$. dumosus diidentifikasi kembali menjadi D. Subbiglandulosus.

Kata kunci: Annonaceae memanjat, Desmos dumosus, Borneo, pemeriksaan penamaan, taksonomi.

Isna Arofatun Nikmah, Tatik Chikmawati \& Rugayah. 2019. Reinstatement of Desmos subbiglandulosus (Annonaceae) in Borneo. Floribunda 6(3): 98-102. - Desmos subbiglandulosus (Miq.) Merr., previously placed as a synonym of Desmos dumosus (Roxb.) Saff., is reinstated based on the examination of herbarium specimens and type material of D. subbiglandulosus from Borneo deposited in Herbarium Bogoriense. The specimens of $D$. subbiglandulosus and $D$. dumosus are morphologically distinct. All the specimens Desmos from Borneo previously identified as $D$. dumosus should belong to $D$. subbiglandulosus.

Keywords: Climbing Annonaceae, Desmos dumosus, Borneo, nomenclatural reassessment, taxonomy.

Desmos Lour. is a woody climber or shrub genus in Annonaceae (Magnoliales), consisting of around 25 species widely distributed throughout Asia and Australia (Sinclair 1955). Since the name Desmos was published by Loureiro (1790), this taxon has been studied by many researchers, especially because of its controversial status with its closely related genus, Dasymaschalon (Hook. f. \& Thomson) Dalla Torre \& Harms. The latest molecular phylogenetic investigation by Chatrou et al. (2012) showed that Desmos belongs to the same clade with Dasymaschalon in the Uvariae tribe. However, a subsequent study by Guo et al. (2017), with the addition of five genera, showed that Desmos is sister clade with Dasymaschalon. Consequently, the taxonomical status of Desmos as a distinct genus is still unclear.

Previous research on Desmos in Western Malesia was studied by $\mathrm{Ng}$ (2010) who confirmed Desmos dumosus (Roxb.) Saff. Ng (2010) reported that $D$. dumosus was not occured in Malesia as mentioned by Ridley (1922) and Sinclair (1955) which was followed by Turner $(2011,2012)$ in treating the Bornean climbing Annonaceae, including Desmos. Otherwise, $\mathrm{Ng}$ (2010) published a new species which is actually another species $(D$. subbiglandulosus) which type of specimen is from Borneo. In this study, we confirm the misdetermination by Ridley (1922), Sinclair (1955), Turner $(2011,2012)$, and Ng (2010) and clear up the taxonomic confusion between $D$. dumosus, D. sinclairii, and D. subbiglandulosus based on the specimens from Borneo. Therefore, we deem it necessary to publish the results of our study of Bornean Desmos.

\section{MATERIALS AND METHODS}

Bornean specimens of the genus Desmos from various herbaria (BO, SAN, SING, and WAN) were examined during this study and used in the preparation of morphological descriptions. Digital records were also studied from the $\mathrm{L}$ herbarium. When a specimen has been seen directly, an exclamation mark (!) is given. 


\section{RESULT AND DISCUSSION}

In 1865, Miquel described Unona subbiglandulosa as a new species based on the specimen type from Martapoera, Borneo with Korthals as specimen collector. Miquel (1865) explained that $U$. subbligandulosa has a pale leaf abaxially, having glands on both sides of their leaf base, apex slightly obtuse or obtuse, glabrous adaxially, pubescent indumentum on the venation, flower leafopposed or sub-leaf-opposed, 1 bract, petals lanceolate, stipe pubescent, 1 to 5 articulated seeds in each fruit and there is constriction between the seeds. All these characters, especially the presence of a pair of glands at the base of leaves and fruit consisting more than one seed that constricted between the seeds, indicates that this species is a member of Desmos. Merril (1915) revised some species of Unona found in the Philippines and transferred them to Desmos. One of them is $D$. subbiglandulosus which was previously named $U$. subbiglandulosa (Merril 1915).

Ridley (1922) and Sinclair (1955) both recorded the occurrence of $D$. dumosus in the Malay Peninsula. Sinclair (1955) also treated D. subbiglandulosus (Miq.) Merr. and Oxymitra monilifera as a synonym of $D$. dumosus (Roxb.) Saff. Meanwhile, the type specimen of $D$. dumosus is from Sylhet, Bangladesh, and has large flowers. In his description, Sinclair (1955) provides broader delimitation on this species. Sinclair (1955) stated that $D$. dumosus is a species that has high morphological variation. In his publications, Sinclair (1955) also stated that the variety previously described by Craib as $D$. dumosus var. glabrior from Thailand could be an intermediate form between $D$. dumosus and D. chinensis.

Turner $(2011,2012)$, in his treatment of Bornean climbing Annonaceae, followed Sinclair who considered $D$. subbiglandulosus to be a synonym of $D$. dumosus. In contrast $\mathrm{Ng}$ (2010), in her revision of Desmos from Thailand, Peninsular Malaysia, and Sumatra, critically examined all specimens of Desmos with very dense indument on their leaves and concluded that the specimen examined by Sinclair (1955) belonged to a species different from $D$. dumosus. She then proposed it as a new species in her thesis as D. sinclairii $\mathrm{KW}$ $\mathrm{Ng}$. She found that $D$. dumosus did not occur in the Malay Peninsula or Sumatra, then Ng (2010) separated these two species. The type specimen proposed by KW Ng (2010) is Burkill and Haniff 17061 from Peninsular Malaysia. The type of specimen used by $\mathrm{Ng}$ (2010) is incomplete specimen, so to clarify D. subbiglandulosus, the author uses one of the specimens examined of $\mathrm{Ng}$ (2010), $H M B 1812$ (Fig. 1).

In this study based on the morphological observations on Desmos in Borneo, we concluded that $D$. dumosus identified by previous researchers and $D$. sinclairii have similar diagnostic features to D. subbiglandulosus and distinctly different with D. dumosus s.str, especially on the leaf indumentum abaxially, tertiary venation, petiole indumentum, flower position, pedicel bract, sepal shape, outer petal shape, connectivum shape, monocarp shape, monocarp apex, and diameter of stipe (Table 1). Unfortunately, $\mathrm{Ng}$ did not examine Desmos specimens from Borneo and she treated $D$. subbiglandulosus as a synonym of $D$. dumosus in her thesis. Therefore $D$. sinclairii described by $\mathrm{Ng}$ (2010) as a new species in her thesis should be treated as a synonym of $D$. subbiglandulosus (Miq.) Merr. Based on our observation on 22 Desmos specimens from Borneo, we agree with $\mathrm{Ng}$ (2010) to separate D. dumosus sensu Sinclair into two taxa and resurrect D. subbiglandulosus (Miq.) Merr. With this resur-rection, there is a significant change in the distribution of $D$. dumosus and $D$. subbiglandulosus species. All specimens of Desmos in Borneo previously placed in $D$. dumosus are re-identified as $D$. subbiglandulosus.

Not all the morphological characters previously used by $\mathrm{Ng}$ (2010) can be used to differentiate D. subbiglandulosus and D. dumosus. $\mathrm{Ng}$ (2010) stated that D. subbiglandulosus has a less densely indument than $D$. dumosus but some specimens of D. subbiglandulosus in Borneo have the same indument density as $D$. dumosus, such as $P B U 342$. The shape of the leaves is also used as a character to distinguish $D$. subbiglandulosus and D. dumosus by $\mathrm{Ng}$ (2010). Morphological examination of D. subbiglandulosus showed that the leaf shapes of these two species have similarities. The shape of the seeds also cannot be used to differentiate these two species because $D$. subbiglandulosus is a species that has a wide geographical distribution and has variations in the shape of the seeds, i.e. globose (mostly) and ellipsoid. 


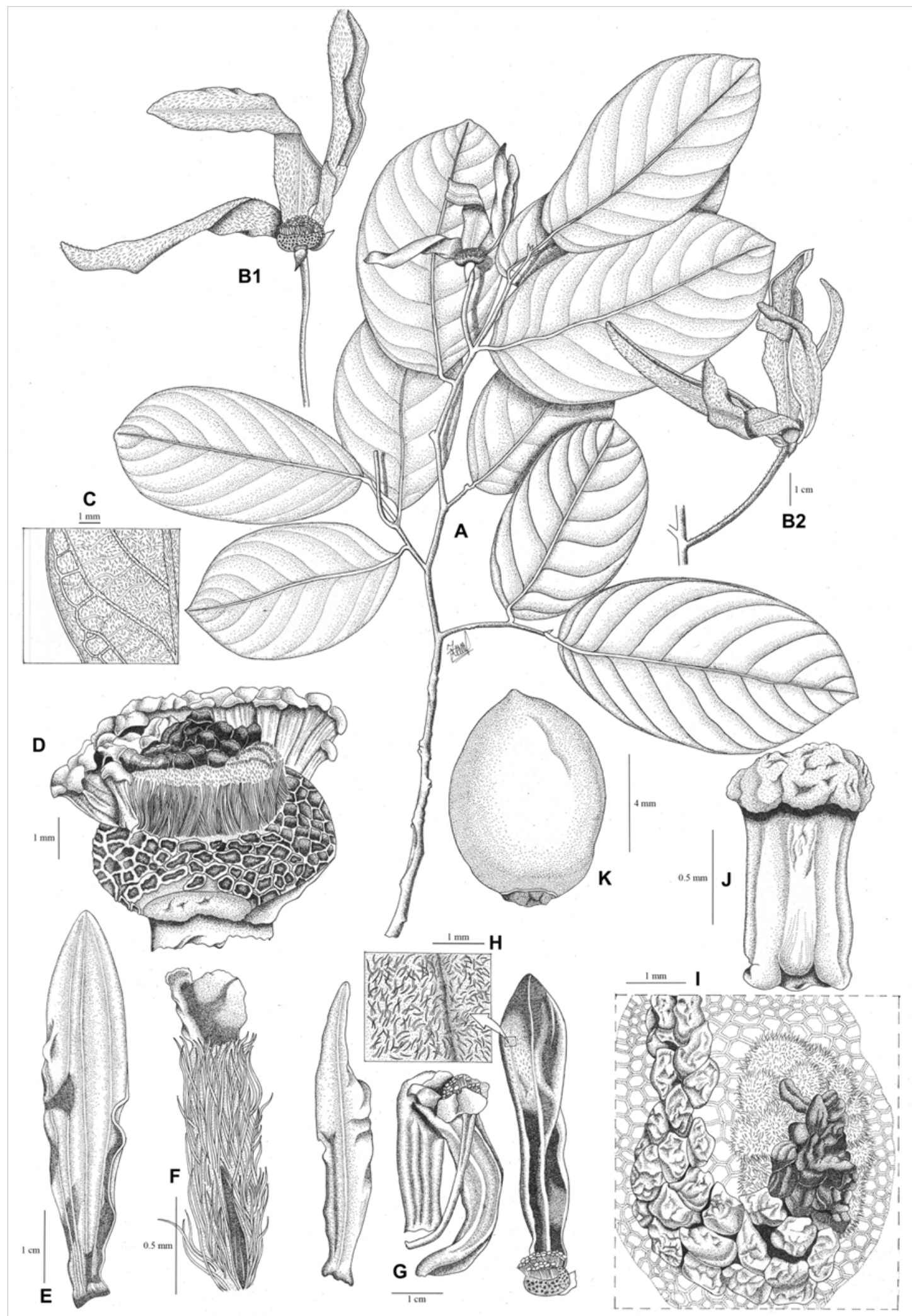

Figure 1. Morphology of D. subbiglandulosus (Miq.)Merr. A. Flowering branches; B1.Outer and inner petals arrangement with ovate sepals; B2. Sub-leaf-opposed flower; C: Eucamptodromous venation; D. Flat torus; E.Lanceolate-elliptic outer petals; F. Very densely indumentum on ovary; G. Lanceolate inner petal; H. Very densely hairy indumentum on outer petals abaxially; I. Slightly prominent connectivum; J.Stamen and connectivum glabrous; K. Seed globose. [Based on: $H M B$ 1812 (BO!)]. Drawing by Zakaria Al Anshori. 
Table 1. Morphological comparison between D. subbiglandulosus and D. dumosus

\begin{tabular}{|c|c|c|c|}
\hline No. & Characters & D. subbiglandulosus & D. dumosus \\
\hline 1 & Leaf indumentum abaxially & $\begin{array}{l}\text { Erect and short, most of } \\
\text { the trichomes are dark } \\
\text { brown and undulated with } \\
\text { some are black, longer } \\
\text { and strongly erect }\end{array}$ & $\begin{array}{l}\text { Slightly erect and long, } \\
\text { most of the trichomes are } \\
\text { light brown or golden } \\
\text { yellow without any longer } \\
\text { black trichomes }\end{array}$ \\
\hline 2 & Tertiary venation & Distinctly percurrent & Obscurely percurrent \\
\hline 3 & Petiole indumentum & $\begin{array}{l}\text { Erect and short, most of } \\
\text { the trichomes are dark } \\
\text { brown and undulated with } \\
\text { some are black trichomes }\end{array}$ & $\begin{array}{l}\text { Sub-erect and long, most } \\
\text { of the trichomes are light } \\
\text { brown or golden yellow } \\
\text { without any black } \\
\text { trichomes }\end{array}$ \\
\hline 4 & Flower position & $\begin{array}{l}\text { Sub-leaf-opposed and } \\
\text { sometimes supra-axillary }\end{array}$ & Leaf-opposed \\
\hline 5 & Pedicel bract & 1 & 1 , rarely 2 \\
\hline 6 & Sepal shape & Ovate & Broadly ovate \\
\hline 7 & Outer petal shape & Lanceolate-elliptic & Obovate \\
\hline 8 & Connectivum shape & $\begin{array}{l}\text { Rounded and slightly } \\
\text { prominent }\end{array}$ & Truncate \\
\hline 9 & Monocarp shape & Globose & Ellipsoid \\
\hline 10 & Monocarp apex & Apiculate & Obtuse \\
\hline 11 & Diameter of stipe & Ca. $1 \mathrm{~mm}$ or less & Ca. $1-1.2 \mathrm{~mm}$ \\
\hline
\end{tabular}

\section{TAXONOMIC TREATMENT}

Desmos subbiglandulosus (Miq.) Merr., Philipp. J. Sci. 10: 235 (1915). - Unona subbiglandulosa Miq., Ann. Mus. Bot. Lugduno-Batav. 2: 11 (1865). Type: Borneo: Martapoera, date unknown, $P$. W. Korthals s.n. (holotype: L!-image seen [L 0182002]).

Oxymitra monifera Merr., Univ. Calif. Publ. Bot. 15: 73 (1929).—Dasymaschalon moniliferum (Merr.) P.T. Li, Acta Phytotax. Sin. 14: 104 (1976). Type: Borneo: Tawao: Elphinstone Province: British North Borneo, A.D.E. Elmer \#20525 (holotype: BM!-image seen [BM000815201]; Isotype: $\mathrm{BO} !)$.

[Desmos sinclairii $\mathrm{KW} \mathrm{Ng}$, in Systematics of Desmos (Annonaceae) in Thailand, Peninsular Malaysia and Sumatra, unpublished name, M.Phil. Thesis, The University of Hongkong: 74 (2010).]

Desmos dumosus auct. non (Roxb.) Saff., Sinclair, Gard. Bull., Singapore 14: 268 (1955).

Scandent shrub or climber $15 \mathrm{~m}$ in high, 3 $\mathrm{cm}$ in diameter. Twigs densely hairy, young twigs very densely hairy, lenticellate (dark brown). Leaf laminas subcoriaceous, oblong or obovate (most- ly), 3.8-22.2 × 3.5-8.1 cm, apex acuminate or acute or obtuse (mostly), base rounded with a pair of glands, adaxial surfaces glabrous, abaxial subglabrous to densely hairy; midrib faint and tomentose adaxially,midrib very prominent and tomentose abaxially; secondary venation $8-13$ very prominent abaxially, faint adaxially; tertiary venation distincly percurrent; petiole $5.2-7.7 \mathrm{~mm}$ long, 1-2.4 mm diameter, tomentose. Flower subleaf-opposed; pedicels 20-42 mm long, $1 \mathrm{~mm}$ diameter, very densely hairy; pedicel bract 1 , lanceolate, submedian; sepals 3 , ovate, $5-8 \mathrm{~mm}$ long, reflexed, very densely hairy; petals yellowish green; outer petals 3, lanceolate-elliptic, 35-50 × 6 $-15 \mathrm{~mm}$, reflexed, almost glabrous; inner petals 3 , narrowly lanceolate, $30-44 \times 6-15 \mathrm{~mm}$, reflexed, very densely hairy; stamens many, c. $1 \mathrm{~mm}$ long, connectivum rounded-slightly prominent, glabrous; carpels many, ovary very densely hairy, stigma $0.3-0.5 \mathrm{~mm}$ long, clavate, glabrous. Fruits moniliform; fruiting pedicel $22-22.5 \times 1.3-1.6$ $\mathrm{mm}$ diameter, subglabrous to very densely hairy; no calyx persisted; monocarp $3 \mathrm{~cm}$ long by $5.5-6$ mm wide, 1-5 seed per monocarp, surface hairy, rounded with constriction between seeds, apex apiculate, base rounded, glabrous surface; stipe 7- 
$17 \times 1-1.2 \mathrm{~mm}$, glabrous to very densely hairy; seeds globose, 6-9 × 5-6 mm wide, smooth.

Distribution. Peninsular Malaysia and Borneo. In Borneo collected from Brunei, Sabah, Sarawak, Kalimantan (West, Central and East).

Habitat and ecology. Primary forest, secondary forest, riverine forest, peat swamp forest; mixed Dipterocarp, Myrtaceae, Euphorbiaceae, Myristicaceae on red clay or greyish soil; elevation 25-600 m.

Phenology. Flowering specimens collected on April. Fruiting specimens collected on March, April, May and June.

Specimens examined: Borneo: BRUNEI DARUSSALAM Belait Labi, Valley of sungei Rampayoh, alluvial forest, valley bottom, $25 \mathrm{~m}$, s. dat., JD 7320 (SAN!). SARAWAK: Tatau, Ulu Merirai, gua Naga, 11 July 2005, Julia S, Rantai $J$ and Army K S 95749 (SING!). SABAH: Tawao, Elphinstone Province, British North Borneo, A.D.E. Elmer20525(BO!, BM). District Kalabakan, gunong Rara forest reserve, growth at the side of a hill, 13 March 1982, Fedilis Krispinus SAN 91913 (SAN!, SING!, L). District Lahad Datu, Mile 12, main road Silam area, Kalumpang, secondary forest, 17 October 1961, Muin Chai SAN 26678 (SAN!, SING!, L). WEST KALIMANTAN: Sintang, Bukit Baka National Park, ridge and environs above Batu Bertanam, mixed Dipterocarp forest, associates include Shorea, Myrtaceae, Euphorbiaceae, Myristicaceae, red clay soil, 350 m, 7 November 1993, $A C 612$ (BO!, SING!, L). CENTRAL KALIMANTAN: Bukit Rawis, Natural Tourism Park Tangkling, peat swamp forest, 23 May 2006, IE 0149 (BO!). Base camp P.B.U and environs, riverine forest, 6 June 1990, Kade Sidyasa PBU342 (BO!, L). EAST KALIMANTAN: Inhutani Area Batu Ampar, Bukit Bangkirai, jalan Shorea, logged over forest, (E 01 01.907'S 116 49.597'), 148 m, 30 April 1996, PK1457 (BO!, SAN!, WAN!, L). KPC Area Bengalon, Kuari, secondary forest along logging road (117 37.109' E; 00 50.802' N), 134 m, 20 April 1996, Arifin Zainal and Arbainsyah AA1822 (BO!). SOUTH KALIMANTAN: Martapoera, date unknown, P. W. Korthals s.n. (L). Peninsular Malaysia: PAHANG: 8 miles of Kuala Lipis, 17 November 1924, I. H. Burkill \& M. Haniff 17061 (BO!). SINGAPORE: Nature Reserve by McRitcie Reservoir, 24 April 1959, HMB 1812 (BO!, L). India: Assam: Silhet, F. De Silva (Wall. Cat 6429a) (K).

\section{ACKNOWLEDGEMENT}

We are grateful to the Ministry of Research, Technology and Higher Education of Indonesia for PMDSU scholarship. We thank the curators of BO, SAN, SING, WAN for allowing the authors to observe specimens. We also thank the curators of the Naturalis Herbarium, Leiden (L) for providing access to their collections. The authors especially thank Ada Kwok Wun Ng for her critical examination and successful differentiation of some specimens of Desmos dumosus. We also thank Mr. Zakaria Al Anshori for the beautiful line drawing.

\section{REFERENCES}

Chatrou LW, Pirie MD, Erkens RHJ, Couvreur TLP, Neubig KM, Abbott JR, Mols JB, Maas JW, Saunders RMK \& Chase MW. 2012. A new subfamilial and tribal classification of the pantropical flowering plant family Annonaceae informed by molecular phylogenetics. Botanical Journal of the Linnean Society 169: 5-40.

Guo X, Tang CC, Thomas DC, Couvreur TLP \& Saunders RMK. 2017. A mega-phylogeny of the Annonaceae: Taxonomic placement of five enigmatic genera and recognition of a new tribe, Phoenicantheae. Scientific Reports 7: 7323 .

Loureiro Jde. 1790. Flora Cochinchinensis. Expensis Academicis. Lisbon.

Merrill ED. 1915. Studies on Philippine Annonaceae, I. The Philippine Journal of Science 10: 227-264.

Miquel FAW. 1865. Annonaceae Archipelagi Indici. Annales Musei Botanici LugdunoBatavi 2: 1-45.

Ng KW. 2010. Systematics of Desmos (Annonaceae) in Thailand, Peninsular Malaysia and Sumatra. The University of Hong Kong. Hong Kong.

Ridley HN. 1922. The flora of the Malay Peninsula, I. L Reeve. London.

Sinclair J. 1955. A revision of the Malayan Annonaceae. Gardens' Bulletin Singapore14: 149 -516 .

Turner IM. 2011. A catalogue of the Annonaceae of Borneo. Phytotaxa. 36: 1-120.

Turner IM. 2012. Annonaceae of Borneo: a review of the climbing species. Gardens' Bulletin Singapore 64: 371-479. 